\title{
原算論文
}

\section{樹形モデルを用いた スギ・ヒノキの枝貯留容量の推定}

\author{
大竹 奈津子 1） 高瀬恵次 2) 戎 信宏 2) \\ 1) 愛媛大学大学院連合農学研究科 \\ （干790-8566 愛媛県松山市樽味3-5-7) \\ 2)愛媛大学農学部 \\ （テ790-8566 愛媛県松山市樽味3-5-7)
}

\begin{abstract}
森林整備が樹冠遮断に及ぼす影響を明らかにするため, まず，樹種（スギとヒノキ）や樹高の異なる立木を対象 に枝貯留容量実験を行った，次に，枝打ちによる枝葉の減少，除伐・間伐による立木密度の減少など，森林整備の 影響を考慮に入れた枝貯留容量の検討を行うため, 樹形特性の計測を行い樹形モデルの構築を試みた.そして, 枝貯 留容量実験の結果から得られた単木貯留容量と樹形モデルによる推定值を比較したところ, 両者は概ね一致した。ま た, 試験地内で観測された林内雨量から樹冠貯留容量を求め, モデル推定值と比べたところほぼ類似した值となっ た. さらに, 従来の研究で報告されている樹冠貯留容量と樹形モデルによって算出した推定值を比較すると, 過去 の報告值は樹形モデルの推定範囲内となった.
\end{abstract}

キーワード：枝貯留容量, 樹冠貯留容量, 一次枝, 樹形モデル

\section{I 、はじめに}

近年, 全国各地で渇水や洪水などの水問題が頻繁 に発生している. 従来, このような水問題解決のた めの有効な手段とされてきたダム築造などハード な対策は, 社会的, 環境的な観点から困難な状況 となっており, かわって森林の持つ洪水調節機能や 水源涵養機能などを活かした解決に大きな期待が寄 せられるようになった。しかしながら，これら森林 の公益的機能については自然科学的な実証データが そしく, その機能を十分に発揮させるための森林整 備や管理の方法が具体的に提言できていないのが現 状である。

このうち, 間伐や枝打ちなどの森林整備は, 立木 密度・枝量などの減少を通して, 流域の水循環に直 接関与し, 森林の水に関わる様々な機能に大きな影 響を与えると考えられる。すすおわ，このような森 林整備は, 樹木の枝葉や幹によって遮断される樹冠 貯留量および遮断蒸発量の減少と林内雨量の増加を もたらすことになる。また葉量の減少は無降雨期の 蒸発散量にも大きな影響を与えると予想される.

この樹冠遮断に関しては多くの研究報告があり,
塚本（1992）は人工林の樹冠遮断量が年降水量の2 3割と大きなウエイトを占めると報告している。さ らに樹木に付着貯留した雨 (樹冠貯留量) は, 遮断 蒸発として絶えず大気へと戻るため, これは遮断蒸 発量を支配する要因の一つである。この樹冠貯留量 については, 田崎（1950）や藤井（1959）の実験, 鈴木ら（1979）や服部ら（1983）の林外雨量と林内 雨量との統計的解析, 端野ら (1991) や吉田ら （1993）の貯留型モデルなどにより推定されている. また，その最大值である樹冠貯留容量を樹冠特性か ら検討した研究として, 樹高や枝本数との関係から 推定した石原ら（1970）や葉面積指数との関係から 推定した石坦ら (1989), Llorens et al. (2000) らの 研究がある.さらに, Hutchings et al. (1988) は各 枝位置の枝葉量と枝貯留容量との関係から樹冠貯留 容量を推定している。しかしながらこれらの研究で は, 樹冠構造の変化が樹冠貯留容量に与える影響に ついては触れられていない, そこで本研究では, 森 林整備あるいは樹木の生長に伴う森林構造の変化を 考慮した樹冠貯留モデルを構築し, 樹冠遮断特性を 明らかにすることを目的とした。 
本論文では，まず樹冠貯留容量の大部分を占める と考えられる枝と葉の貯留特性を定量的に評価する ため，樹種や樹高の異なる立木を対象に枝貯留容量 の実験を行った。次に，枝打ちゃ間伐による枝葉の 減少が枝貯留容量に与える影響を明らかにするた め, 枝長，枝径，枝の位置などを詳細に検討し，樹 形特性のモデル化を試みた。そして最後に，この樹 形モデルと実験により得られた枝貯留容量とを組み 合わせることで, 樹冠貯留容量を推定した。このよ うな樹形モデルによる解析を行うことで, 間伐や枝 打ちなどの森林整備が樹冠貯留容量に与える影響を 把握でき，ひいては森林の水源涵養機能にとってょ り適切な森林整備や森林管理の方法を提案できると 期待される.

\section{II ．樹形の計測および枝野留容量の実験方法}

\section{1. 伐木地の概要}

樹形特性の計測と立木の枝貯留容量の測定を行う ため, 樹種, 胸高直径の異なる立木を現地にて伐倒 した。そしてその場で樹高, 枝位置, 枝径および枝 長等の樹形特性の計測を行った後, 採取した枝葉を 実験室に持ち帰り，枝貯留容量の実験を行った。 計測及び測定の対象とした試験木の詳細を表ー1に 示す.

スギ (Cryptomeria japonica) については, 愛媛大 学農学部附属演習林内 (北緯 $33^{\circ} 53^{\prime}$, 東経 $132^{\circ} 54^{\prime}$ ) で2本, 大洲市杭瀬地区内 (北緯 $38^{\circ} 28^{\prime}$, 東経 $132^{\circ}$ $34^{\prime}$ ) で2本を伐木した。演習林内の伐木場所は, 斜 面傾斜 $20^{\circ}$ の南向き斜面で, 間伐が十分に行われて いないため，立木密度は扮よそ3,000本/ ha と比較的 密である。林齢は13年と若く，したがって樹高は低 く, 胸高直径も小さい. 一方, 杭瀬地区の伐木場所 は斜面傾斜 $29^{\circ}$ の西向き斜面で, 間伐や枝打ち等の 森林整備が行われた地区内である。したがって，立

\section{表 -1 試験木の概要}

Table 1 Characteristics of trees for experiments.

\begin{tabular}{c|cccc|cccc}
\hline \multirow{2}{*}{ 試験木NO. } & \multicolumn{4}{|c|}{ スギ } & \multicolumn{4}{c}{ ヒノキ } \\
\cline { 2 - 10 } & 1 & 2 & 3 & 4 & 1 & 2 & 3 & 4 \\
\hline 胸高直径 $(\mathrm{cm})$ & 10.4 & 14.4 & 24.2 & 26.8 & 9.2 & 13.8 & 17.5 & 25.8 \\
樹高 $(\mathrm{m})$ & 9.4 & 10.8 & 19.8 & 20.4 & 7.0 & 8.8 & 11.0 & 15.3 \\
生枝下高 $(\mathrm{m})$ & 6.8 & 9.0 & 8.1 & 7.7 & 4.7 & 5.8 & 8.0 & 7.2 \\
林齢(年) & 13 & 13 & 39 & 39 & 19 & 15 & 19 & 34 \\
立木密度(本/ha) & 3,000 & 3,000 & 1,100 & 1,100 & 3,300 & 2,300 & 3,300 & 1,500 \\
\hline
\end{tabular}

木密度は演習林に比べて小さく，1,100本/haである. 林齢は39年で樹高は高く，胸高直径も大きい．

ヒノキ (Chamaecyparis obtusa) については, 同 演習林内の斜面傾斜 $20^{\circ}$ の北東向き斜面で 19 年生の 樹木 2 本, 斜面傾斜 $19^{\circ}$ の南西向き斜面で 15 年生の 樹木1本，斜面傾斜 $26^{\circ}$ の南東向き斜面で 34 年生の 樹木1本, 計4本を伐木した。立木密度は第1地点が 最も密で3,300本/ ha, 次いで第2の地点が2,300本/ha, 第3の地点が1,500本/ haであった.

\section{2. 樹形特性の計測方法}

スギやヒノキのような針葉樹は, 根元から幹が まっすぐに伸び，枝は幹を中心に放射状に枝分かれ し, 広葉樹に比べ比較的単純な樹冠構造を形成して いる.

本研究では現地で立木を伐倒し，まず単木の樹高， 胸高直径を測定した。その後, 幹から直接分岐する 全ての一次枝を対象に, 梢頭からの距離, 長さ, 直 径の測定を行った（図一1）。従来の樹形測定では, 写真撮影やトランシット測量による3次元の計測が 主であるが (竹下, 1985), 本研究の目的は, 樹高 と枝長，枝径から枝貯留容量の推定を行うことにあ るので，一次枝の方位角等の測定は行わなかった。

\section{3. 枝貯留容量の実験方法}

上述のような樹形特性を現地で測定後，一次枝を 切り落として実験室に持ち帰り, 以下のような方法 で枝貯留容量を測定した。

まず図一1のように，一次枝を秤に吊し，霧吹き で十分に散水した。そして，これ以上水が貯留され なくなった状態を重量変化により確認し, 散水終了 後，枝から水滴が落ちなくなった状態（10分後）で 枝貯留容量の計測を行った。 なお，本数の多い短長
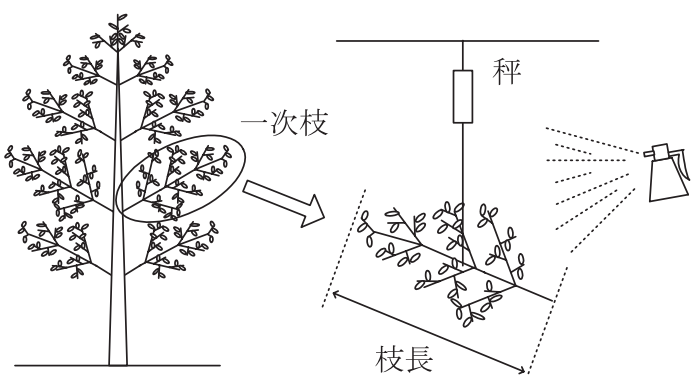

図 -1 枝貯留容量実験

Fig.1 Experiment of water storage capacity on first order branch. 

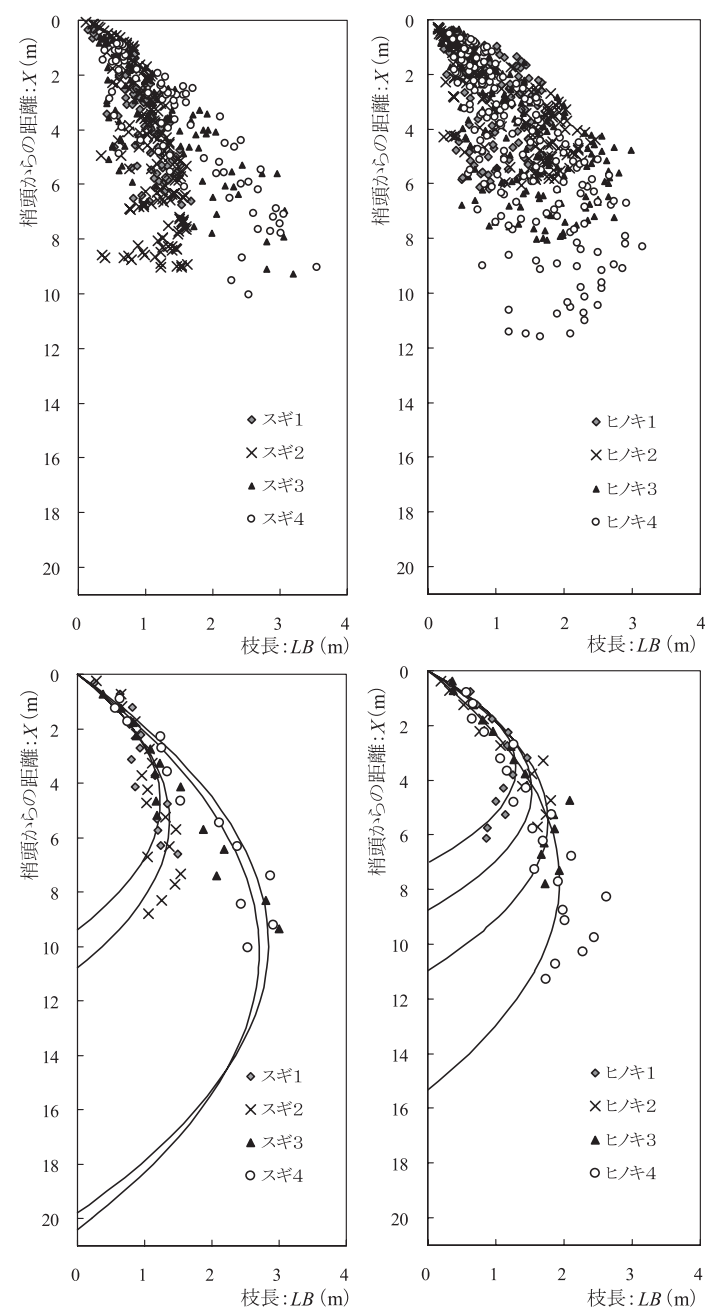

図-2 梢頭からの距離と枝長との関係（左：スギ, 右：ヒノキ, 上：全計測值，下：平均值）

Fig.2 Relationships between a distance from the top of tree and a length of branch. In these figures, left and right groups show the relation for Cryptomeria japonica and Chamaecyparis obtuse and upper and lower groups show the data of all branches and averaged one on $0.5 \mathrm{~m}$ interval, respectively.

枝については適宜選択して実験を行い，実験に用い なかった短長枝の貯留容量については, 後述する枝 長と枝貯留容量の関係式によって求めた。

\section{III. 樹形のモデル化}

\section{1. 一次枝長と枝位置の関係}

図一2に計測の結果得られた一次枝の枝長と梢頭 からの距離の関係を示す。なお，図中のスギ1〜4と
ヒノキ1〜4の試験木は表一1に対応している．図一 2の上2つの図は計測したすべての枝をプロットした もの, 下 $2 つ の$ 図は梢頭からの距離 $0.5 \mathrm{~m}$ 間隔の平均 值をプロットしたものである。このように，ある梢 頭からの位置における枝長は必ずしも一定ではなく 大きなばらつきを示すが, 本研究では樹冠貯留容量 の推定を目的としているので, 枝の外形よりも枝平 均長に焦点を当て, 回帰式を求めた。その結果, 両 者の関係は（1）式に示すように，梢頭からのある 位置を頂点とする二次曲線で近似できることがわ かった。

$$
L B(X)=-\operatorname{ax}(X-\beta)
$$

ここで, $X$ : 梢頭からの距離 $(\mathrm{m}), L B(X): X$ の位置にお ける一次枝の平均枝長 $(\mathrm{m}), \alpha, \beta$ : 係数である.

さらに, 枝長の計測結果より一次枝の長さが樹高 $H$ の 半分で最大となる傾向にあることがわかったので, (1)式 において $\beta=H$ と仮定すれば次式を得る.

$$
L B(X)=-\alpha x(X-H)
$$

ここで， $\alpha$ : 放物線の形状, すなわち枝の張り方を 表す係数である.

一方， $\alpha$ の值は樹種によって変化するが，それぞ れの樹種に対して樹高との間に図一3に示すような 関係が認められた。そこで，スギとヒノキそれぞれ の

$$
\begin{array}{ll}
\alpha_{\text {sugi }}=0.11 \exp (-0.07 H) & \left(\mathrm{R}^{2}=0.97\right) \\
\alpha_{\text {hinoki }}=0.27 \exp (-0.14 H) & \left(\mathrm{R}^{2}=1.00\right)
\end{array}
$$

ここで, $H$ : 樹高 $(\mathrm{m}), \mathrm{R}^{2}$ : 各回帰式の決定係数 (寄与 率)である.

これより，樹高 $H$ を知ることによって，任意の高
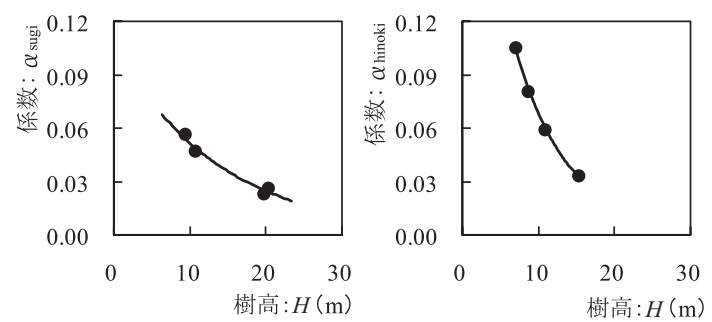

図 -3 樹高 $H$ と係数 $、$ の関係（左：スギ, 右：ヒノキ)

Fig.3 Relationships between a tree height and parameter a. Left and right figures show the relation for Cryptomeria japonica, and Chamaecyparis obtuse, respectively. 
さにおける枝長平均值を推定することが可能となる。

これまでの研究によれば，スギの樹冠の側面形状 は梢頭の尖形部分を除くとパラボラ曲線で表現でき るとされている（竹下，1985，林ら，1997）。しか しながら本研究において, 二次曲線およびパラボラ 曲線により計算した枝長と実測枝長を検討したとこ ろ, 寄与率は前者で 0.71 , 後者で 0.67 となり二次曲 線の方で再現性が高くなった。これは，梢頭部にお ける枝の張り具合や，下層部に打いて枝長が減少し ているようすが（2）式で良く表現されているため であると考えられる，以上のことから，本研究では

（2）式によって，樹形の形状を表現することにした.

なお，図一2右下のヒノキ4の下層部で，回帰式の 枝長よりも実際の枝長の方が大きい傾向を示してい るが，これは伐倒の際に，下層部の比較的短い枝が 折れてしまい測定できなかったためである.

また， $a$ に関しては樹高だけでなく立木密度に よって変化する可能性も考えられ，それに関しては 今後の課題とする。また枝径と梢頭からの距離との 関係も同様の解析を行ったが，寄与率は枝長の場合 よりも小さくなった。そのため, 本論文では枝長を 用いて解析を進めることとした。

\section{2. 一次枝の間隔と生枝下高}

単木あたりの貯留容量を推定するには，幹から一 次枝がどのような間隔で, 梢頭からどこまで存在し ているか（生枝下高：梢頭からの位置）を知る必要 がある。生枝下高に関しては，樹木の生育状態，樹 齢，抄よび枝打ちなどによって異なるが，本論で対 象とした立木の生枝下高は表一1のようになった。

次に樹形の計測結果より，一次枝がどのような間 隔で存在しているかを検討した。 スギ，ヒノキそれ

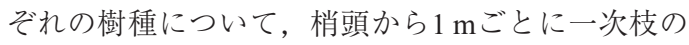
平均間隔距離を求めたところ表一2のようになった。 ヒノキにおいては, 梢頭からの距離に関わらず一次 枝の間隔はほとんど一定であるのに対して，スギは 梢頭からの距離によって変化する結果となった。 ギで下層になるほど枝間隔が大きくなるのは，スギ はヒノキに比べ自然落枝しやすいためと考えられ る。そこで，ヒノキについては一定の枝間隔 $(5 \mathrm{~cm})$ で，スギに関しては梢頭からの距離が $1 \mathrm{~m}$ 増す毎に 枝間隔を $1 \mathrm{~cm}$ 増加するものとした。

以上の検討結果より，一次枝が幹のどの位置から どのような長さで存在しているかを，樹形モデルか ら計算することが可能となった。 またこのモデルは,
表-2 梢頭からの距離と一次枝の平均間隔との関係

Table 2 Value of distance from the top of tree and averaged space between branches.

\begin{tabular}{c|c|c}
\hline \multirow{2}{*}{ 梢頭からの距離 $(\mathrm{m})$} & \multicolumn{2}{|c}{ 平均枝間隔距離 $(\mathrm{m})$} \\
\cline { 2 - 3 } & スギ & ヒノキ \\
\hline $0 \sim 1$ & 0.04 & 0.04 \\
$1 \sim 2$ & 0.06 & 0.05 \\
$2 \sim 3$ & 0.05 & 0.05 \\
$3 \sim 4$ & 0.07 & 0.05 \\
$4 \sim 5$ & 0.08 & 0.05 \\
$5 \sim 6$ & 0.08 & 0.05 \\
$6 \sim 7$ & 0.11 & 0.06 \\
$7 \sim 8$ & 0.11 & 0.06 \\
$8 \sim 9$ & 0.10 & 0.06 \\
$9 \sim 10$ & - & 0.05 \\
$10 \sim 11$ & - & 0.05 \\
$11 \sim 12$ & - & 0.06 \\
\hline 平均 & 0.08 & 0.05 \\
\hline
\end{tabular}

生枝下高の位置を自由に設定できるため，枝打ちに よる枝葉量の変化などの影響も把握できる点で優れ ている.

\section{N . 樹冠鯮留容量の解析結果と考察}

\section{1. 枝貯留容量と枝長・枝径の関係}

図一4には，前述のような方法で測定した一本一 本の枝貯留容量と枝長抒よび枝径との関係を示す. 図一4のa）が枝貯留容量 $S C B$ と枝長 $L B$ の関係，b) が枝貯留容量 $S C B$ と枝径 $L D$ の関係を表した図であ る。図中の破線と実線は，それぞれスギとヒノキの 枝貯留容量の值を二次曲線で回帰したもので, 回帰 式は以下のようになった.

\section{<枝貯留容量と枝長の関係 $>$} スギ：

$$
S C B_{\text {sugi }}=38.52 L B^{2}+45.12 L B \quad\left(\mathrm{R}^{2}=0.82\right)
$$

ヒノキ：

$$
S C B_{\text {hinoki }}=39.01 L B^{2}-3.62 L B \quad\left(\mathrm{R}^{2}=0.67\right)
$$

\section{<枝貯留容量と枝径の関係 $>$} スギ：

$$
S C B_{\text {sugi }}=17.74 L D^{2}+45.01 L D \quad\left(\mathrm{R}^{2}=0.76\right)
$$

ヒノキ：

$$
S C B_{\text {hindi }}=31.65 L D^{2}+2.79 L D \quad\left(\mathrm{R}^{2}=0.87\right)
$$



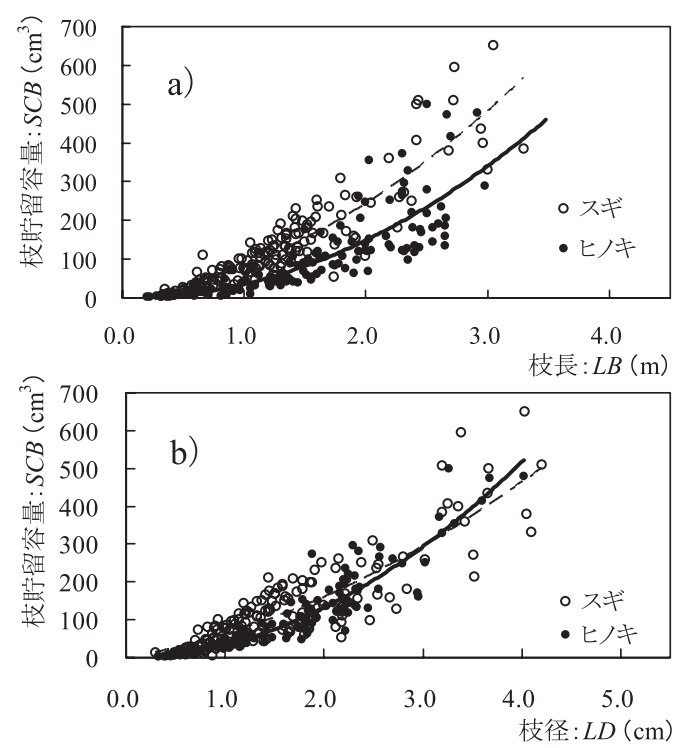

図-4 a) 枝貯留容量 $S C B$ と枝長 $L B$ の関係 b) 枝貯留容 量 $S C B$ と枝径 $L D$ の関係

Fig.4 a) Relationships between storage capacity on a branch and length of the branch b) Relationships between storage capacity on a branch and diameters of the branch.

図－4のa）および（5）式，(6）式で表されるよう に枝貯留容量と枝長の関係は，スギに比べてヒノキ ではばらつきが大きいものの二次曲線によって近似 できる。また，同じ枝長に対する枝貯留容量は樹種 で違いがあり，スギはヒノキよりも大きいことがわ かる。，一方，枝径と枝貯留容量の関係も図-4のb) のように二次曲線によって近似できるが, 同じ枝径 に対する枝貯留容量は樹種でほとんど違いがないこ とがわかった。
なお，次に述べる樹形モデルによる単木貯留容量 の推定には, 前述したように樹形モデルの主要な変 数として枝長を用いたことから，(5)，（6）式の枝 貯留容量と枝長の関係を用いた。

（6）式では $L B か ゙ 9.2 \mathrm{~cm}$ 以下の時 $S C B$ はマイナス 值になるが, 図一4から明らかなように, 実測の $S C B$ は非常に小さいので，この式を適用する時に は $S C B=0$ とした。

またこの枝貯留容量は, 基本的には枝葉面積に比 例すると考えられる。そこで枝葉面積も測定し, 枝 貯留容量との関係を検討した結果，両者の間に高い 線形関係が認められた。

\section{2. 樹形モデルによる単木貯留容量の推定}

ここでは, 単木貯留容量を立木1本の樹冠に付着 貯留される水量と定義し, 単木から伸びる全ての一 次枝の枝貯留容量の総量として求めた. 以下では, 実験で得られた枝貯留容量から算出した単木貯留容 量と, 樹形モデルを用いて推定した単木貯留容量に ついて比較・検討を行った。

実験結果に基づく単木貯留容量の計算では, 伐倒 時に落枝し枝長が測定できなかった一次枝の貯留容 量は, 痕跡より求めた枝径を用い（7），（8）式によ り計算した。

次に樹形モデルによる単木貯留容量の算出手順を 説明する (図一5参照)。まず，それぞれの樹種（本 論ではスギ・ヒノキ) について, 現地で樹高と生枝 下高を測定し，表一2から枝間隔を定めれば，梢頭 からの一次枝の位置が決定できる。そして, 一次枝 の位置から，(2)，（3），(4）式により平均枝長が求

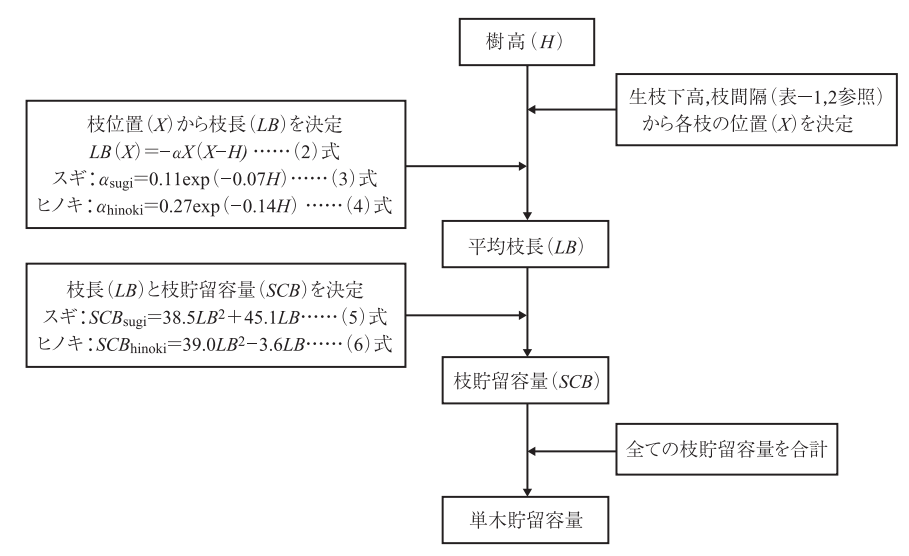

図-5＼cjkstart樹形モデルによる単木貯留容量の算出手順

Fig.5 Step in calculating the storage capacity on a tree by the model. 


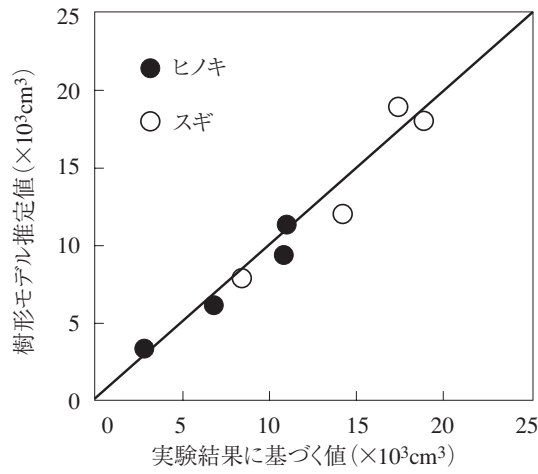

図-6 樹形モデルと実験結果に基づく単木貯留容量の 比較

Fig.6 Comparison between estimated volume of storage capacity on a tree by the model and calculated one using experimental results.

まり，さらに，枝長と枝貯留容量の関係（5），(6) 式から枝貯留容量が算出される。最後に，梢頭から 生枝下高までのそれぞれの位置における一次枝の枝 貯留容量を全て加え単木貯留容量が求められる.

このような手順（樹形モデル）によって推定した 単木貯留容量と実験結果に基づいて求めた単木貯留 容量の比較を図一6に示す。図のように樹形モデル による推定值は, 実験結果に基づく值によく一致し ており，相対誤差はスギで9\%，ヒノキで10\%とな り，概ね良好に推定できたと考えられる。

次にこのモデルを利用して, 杭瀬流域内に設けた 林内雨量観測プロットの樹冠貯留容量を算出した. $10 \times 10 \mathrm{~m}$ の観測プロット内には 10 本のスギが植栽さ れている。表一3に立木の樹高と樹形モデルによる 単木貯留容量の推定值を示す。この結果から, この 試験プロット全体に対する樹冠貯留容量は $1.75 \mathrm{~mm}$
表－3 試験プロット内の樹形モデルによる単木貯留容量 Table 3 Estimated volume of storage capacity on a tree by the model in an experimental plot.

\begin{tabular}{c|c|c}
\hline NO. & 樹高 $(\mathrm{m})$ & 単木貯留容量 $\left(\times 10^{3} \mathrm{~cm}^{3}\right)$ \\
\hline 1 & 16.7 & 17.8 \\
2 & 15.2 & 16.8 \\
3 & 15.2 & 16.8 \\
4 & 25.0 & 16.9 \\
5 & 21.6 & 18.2 \\
6 & 16.5 & 17.7 \\
7 & 15.9 & 17.3 \\
8 & 14.8 & 16.4 \\
9 & 20.1 & 18.5 \\
10 & 18.9 & 18.4 \\
\hline 平均 & 18.0 & 17.5 \\
\hline
\end{tabular}

となった. 一方, 同プロット内での林内雨量の観測 には，林内雨量タンク 12 個と時系列情報を得るため に自記林内雨量計1個を用いて計測を行っているが， これらのデータから樹冠タンクモデル（戎，2006） により推定した值は $1.53 \mathrm{~mm}$ となり, 両者はほぼ近 い值となった。

また, 表一4には樹冠貯留容量に関する従来の研 究結果を示す．表のうち，立木密度と樹高の情報が あり，樹種がスギとヒノキであるものについてはそ れらのデータを引用して, 樹形モデルによる推定值 と比較した。 なお, これらの研究結果についても生 枝下高の情報が得られなかったため，藤森（1975） が示した枝生長停止線と樹高の関係を参考にし, 梢 頭から約 $8 \mathrm{~m}$ を生長停止位置とした。そして本論で は, 生長停止位置を生枝高と考え, これに枝打ちが 行われている可能性を考慮し梢頭から6〜8 mと仮定 して検討を行った。その結果，報告された樹冠貯留

表-4 従来の研究と樹形モデルによる樹冠貯留容量の比較

Table 4 Comparison between estimated value of canopy storage capacity by the model and reported one.

\begin{tabular}{|c|c|c|c|c|c|c|}
\hline 樹種 & 立木密度(本/ha) & 樹高 (m) & 算出方法 & 樹冠貯留容量 $(\mathrm{mm})$ & 樹形モデル推定值 (mm) & 引用 \\
\hline ヒノキ & 1,780 & 12.4 & 実験 & 1.40 & $1.36 \sim 2.20$ & 藤井（1959） \\
\hline ヒノキ & 密* & 11.0 & 遮断能曲線 & 4.00 & $3.09 \sim 4.60$ & 近嵐ら（1983） \\
\hline スギ & 1,467 & 15.2 & 統計的解析 & 2.03 & $1.69 \sim 2.46$ & 佐藤ら（2003） \\
\hline スギ & - & 15.0 & 貯留型 & 1.40 & - & 端野ら（1991） \\
\hline スギ & - & - & 貯留型 & $1.01 \sim 1.51$ & - & 吉田ら（1993） \\
\hline クロマツ & - & 4.3 & 実験 & 1.25 & - & 田崎（1950） \\
\hline アカマツ・ヒノキ & $200 \sim 43,000$ & $2.2 \sim 16.0$ & 統計的解析 & 1.44 & - & 鈴木ら（1979） \\
\hline トウヒ & - & - & 実験 & 2.80 & - & Hutchings et al.(1988) \\
\hline ベイマツ & 800 & 18.0 & 実験 & 2.40 & - & Klaassen et al.(1998) \\
\hline アカマツ & 1,050 & 11 & 実験 & 2.35 & - & Lorens et al. $(2000)$ \\
\hline
\end{tabular}

*立木密度を 4,000 本/haと仮定して樹形モデルによる推定值を求めた。 
容量の值は樹形モデル推定值の範囲内となった.

なお，本論で取り扱った単木貯留容量および樹冠 貯留容量には幹の貯留容量は含まれていない。これ までの研究（たとえば鈴木ら，1979）によると，針 葉樹の樹幹貯留容量は $0.5 \mathrm{~mm}$ 前後と報告されている が, 樹高や森林構造の変化に伴う樹幹貯留容量の解 析については今後の課題としたい.

\section{V.おわりに}

本研究では森林整備が樹冠貯留容量に及ぼす影響 を明らかにするため，まず樹種や樹高の異なる立木 を対象に枝貯留容量実験を行った。枝貯留容量実験 の結果から，一次枝の長さと枝貯留容量との間には 高い相関があることが認められ，また両者の関係は 二次曲線によって近似でき, 樹種によって異なる傾 向を表すことがわかった，次に樹種や樹高に加え， 枝打ちや間伐などの森林整備による枝葉や立木密度 の減少を考慮した樹冠貯留容量の検討を行うため, 樹形特性を計測し，樹形モデルの構築を行った。 ス ギとヒノキの樹形特性の計測に基づいて，樹冠形状 の考察を行った結果, 樹冠形状は樹高Hの二次曲線 で表現でき, さらに，枝の張り方を表す係数 $\alpha$ や枝 間隔は樹種により異なることがわかった。これらの 解析結果から樹形モデルを構築し, 枝貯留容量実験 から得られた回帰式を利用して単木貯留容量の推定 を行ったところ, 樹形モデルによる推定值は実験に 基づく值と概ね一致した。また現地試験プロット内 の樹木を対象にして, 樹形モデルから樹冠貯留容量 を推定したところ, 同プロット内で観測している林 内雨量から推定した值と近い值を示した。ささに, 従来の研究で報告されている樹冠貯留容量と樹形モ デルによる推定值を比較すると, 報告された值は樹 形モデルでの推定範囲内となった。

以上のことから, 樹形モデルは単木貯留容量を推 定する有効なモデルであり，このモデルを用いれば 樹高, 樹種, 立木密度, 生枝下高などの詳細な情報 から, 流域における樹冠貯留容量の推定が可能とな り, 除伐, 間伐, 枝打ち等の森林整備が樹冠貯留容 量に与える影響を定量的に評価できると期待される。

なお，枝の張り方を表す $\alpha$ に関しては，樹高だけ でなく立木密度によって変化する可能性も考えら れ,さらに多くの樹木を対象に, 樹高だけでなく立 木密度の違いも含めた $\alpha$ の变化を検討する必要があ ると考えられる.

\section{謝辞}

文部科学省研究費補助金（基盤研究（B）（2）, 課題番号14360087), 並びに愛媛大学研究開発支援 経費 (研究種目：萌芽的研究) の援助を受けた。こ こに感謝の意を表す。

\section{参考文献}

戎 信宏 (2006): 衛星リモートセンシングと現地観測手法を組み 合わせた森林の水源涵養機能評価, 平成14 17年度科学研究 費補助金 (基盤研究 (B) (2), 課題番号14360087) 研究成果報 告書. pp.25-43.

藤井真一 (1959) :ヒノキ林の遮断雨量に関する試験. 日林誌, 41 (7), pp.262-269.

藤森隆郎 (1975)：枝打ちの技術体系に関する研究. 林試研報, 273, pp.1-74.

端野道夫・吉田 弘・中谷達志 (1991): 実森林樹幹流データによ る降雨遮断モデルの比較検討. 水工学論文集, 35, pp.87-92.

服部重昭・近嵐弘栄・竹内信治 (1982) : ヒノキ林における樹冠遮 断量測定とその微気象学的解析. 林試研報, 318, pp.79-102.

林 拙郎・高橋洋子 (1997): 樹形のモデル化についてースギ・ヒ ノキの場合一. 日林誌, $79(4)$, pp.222-228.

Hutchings, N.J., Mile, R., Crowther, J.M.1988.Canopy storage capacity and its vertical distribution in a Sitka spruce canopy. J.Hydrol 104:161-171.

石垣逸郎・塚本良則 (1989): 樹冠量調節に伴う付着水分量の推 移について. 日林論, 100, pp.699-702.

石原安雄・小葉竹重機 (1970): 雨水流出現象における初期貯留 量についてー樹木による降雨遮断一. 京大防災年報, 13B, pp.69-81.

Klaassen, W., Bosveld, F., de Water, E.1998.Water storage and evaporation as constituents of rainfall interception. J.Hydrol 212-213:pp.36-50.

近嵐弘栄・服部重昭 (1983): ヒノキ林における林内雨量の推定. 林試研報, 324, pp.101-124.

Llorens, P., Gallart, F.2000.A simplified method for forest water storage capacity measurement. J.Hydrol 240:131-144.

佐藤嘉展・久米 篤・大槻恭一・小川滋 (2003) : 樹冠構造の違いが 樹冠通過雨の分布特性に及ぼす影響ースギ林とマテバシイ林に おける樹冠通過雨特性の比較一. 水文・水資源学会誌, 16 (6), pp.605-617.

鈴木雅一・加藤博之・谷 誠・福嶌義宏 (1979): 桐生試験地にお ける樹冠通過雨量, 樹幹流下量, 遮断量の研究 (I) 樹冠通過雨量 と樹幹流下ついて. 日林誌, 61, pp.202-210.

竹下敬司 (1985) : パラボラ樹冠形モデルによるスギ林の構造解 析, 九大演報, 55, pp.55-104.

田崎忠良 (1950): 降雨下に於ける材木の水分付着量について. 日 林誌, $32(2)$, pp.56-61.

塚本良則編 (1992): 森林水文学. 文英堂出版, pp.82-85.

吉田 弘・端野道夫・村岡浩爾 (1993) : 樹幹流データを利用した 降雨遮断タンクモデルによる森林蒸発量の推定法. 水文・水資 源学会誌, 6 (1), pp.19-30.

(受付：2006年7月21日，受理：2007年2月8日） 


\title{
Estimation of Water Storage Capacity on Branches of Japanese Cedar and Cypress by Modeling Tree Form
}

\author{
Natsuko OHTAKE ${ }^{1)}$ Keiji TAKASE ${ }^{2)}$ Nobuhiro EBISU ${ }^{2)}$ \\ 1) The United Graduate School of Agricultural Sciences, Ehime University \\ (3-5-7, Tarumi, Matsuyama, 790-8556 Japan) \\ 2) Faculty of Agriculture, Ehime University \\ (Ehime University, 3-5-7, Tarumi, Matsuyama, 790-8556 Japan)
}

To clarify the effects of forest management on canopy interception, experiments to identify water storage capacity on branches of Japanese cedar and cypress were carried out and a model of tree form was developed to predict the effects of cutting branches and trees. The estimated storage capacity on a tree by the model is almost same as the calculated one using the experiment's result. Furthermore, the model was applied to estimate the storage capacity on trees in actual fields and the estimated values were compared with the calculated one in an experimental plot or reported one by other authors. As a result, it was found that those estimated values correspond reasonably to the calculated or reported values.

Key words : water storage capacity on branches, canopy storage capacity, first order branch, model of tree form 